\title{
Urbanization, Social Mobility, and the Construction of Family Property Relations in a Village Community in Southwest China
}

\author{
Yi Wu \\ Department of Sociology, Anthropology, and Criminal Justice, Clemson University, Clemson, USA \\ Email: ywu5@clemson.edu
}

How to cite this paper: $\mathrm{Wu}, \mathrm{Y}$. (2019). Urbanization, Social Mobility, and the Construction of Family Property Relations in a Village Community in Southwest China. Advances in Anthropology, 9, 151-168. https://doi.org/10.4236/aa.2019.93011

Received: June 4, 2019

Accepted: August 4, 2019

Published: August 7, 2019

Copyright $\odot 2019$ by author(s) and Scientific Research Publishing Inc. This work is licensed under the Creative Commons Attribution-NonCommercial International License (CC BY-NC 4.0).

http://creativecommons.org/licenses/by-nc/4.0/

\section{(c) (i) \& Open Access}

\begin{abstract}
Based on field data collected in a village community in Southwest China during the first decade of the new millennium, this paper shows that urbanization and increased social mobility contributed to growing awareness of individual rights and changing norms regarding domestic property division. Focusing on the division of farmland within rural families, this paper shows that due to the increasing rights-asserting activities of rural individuals, the traditional norms regarding property rights between genders and generations were subject to contestation and negotiation. For instance, as increasing social mobility and economic opportunities caused more and more villagers to leave rural areas, disputes could break out among brothers over what constitutes a fair property division - one based on traditional egalitarianism among sons or one based on labor investment. Also, daughters, who traditionally did not have access to family property, began to demand their shares of land when the family divided. Parents' attitudes towards daughters could also change, offering some daughters the opportunities of succeeding family property. Such new perceptions and behavior regarding property rights can serve as a benchmark/starting point for examining whether and how property relations in rural communities had become more fluid as extensive urbanization and increased rural-urban migration took place in China in the second decade of the new millennium.
\end{abstract}

\section{Keywords}

Property, Individual Rights, Family Division, Rural China

\section{Introduction}

\subsection{Research Problem and Relevance}

This article studies the changing norms and behavior in family property division 
in rural communities in China brought about by urbanization and increased social mobility in the first decade of the new millennium. Field data for this research were collected in Lotus Pond Village in Yuquan, a hinterland county in southwest China, between 2002 and 2010. ${ }^{1}$ Focusing primarily on the rights over land, the most salient form of property, this article reveals some new trends in arranging domestic property division that emerged at the beginning of the new millennium as a result of gradual urbanization and increasing social mobility. First, as increasing social mobility and economic opportunities caused more and more villagers to leave rural areas, disputes could occur among brothers over what constitutes a fair property division-one based on traditional egalitarianism among sons or one based on labor investment. Second, daughters, who traditionally do not have access to family property, began to demand their shares of land when the family divided, or their shares of the compensation when the family-contracted farmland was requisitioned by the government. Third, parents' attitudes towards daughters began to change, offering some daughters the opportunities of succeeding family property.

Domestic property division is an arena where family members define and negotiate property rights, and therefore can provide information on the actual rights of rural individuals. It is both interesting and important to assess the actual rights that rural individuals had in everyday life, because in China, formal ownership rights to rural land has been vested in village collectives from the 1950 s to the present. Starting in the early 1980 s, farmland was distributed to rural households through contracts, and families emerged as the primary units of agricultural production. However, the land rights of rural individuals have never been specified by law. This paper explores the increasing awareness of individual rights in an increasingly urbanized social environment where the land value soared and rural-urban migration became part of everyday life. It reveals that increasing rights-asserting activities had changed interpersonal dynamics within the household and eroded the long-held cultural norms regarding rights and responsibilities between genders and generations. As the first part of a larger project on the changing land rights of rural individuals, this paper can serve as a benchmark/starting point for examining the even more profound changes in rural individuals' perceptions and behavior regarding property rights during the second decade of the new millennium, when the impacts of urbanization and social mobility on rural communities had become even more extensive.

\subsection{Research Methods}

Empirical data for this article were collected through ethnographic fieldwork (October 2002-June 2003, March-June 2004, June 2005, July 2010). During the fieldwork, participant observations, interviews, and documentary research were the primary methods of data collection. As a legal anthropologist, the researcher paid special attention to disputes/disagreements that occurred during the

${ }^{1}$ The names of all places and individuals discussed in this article are pseudonyms. 
process of family division and used the case method to trace the causes and course of a dispute within its social context, for the purpose of identifying the social norms, or changing norms, underlying particular types of rights, as well as identifying the means through which social disruptions are resolved (Llewellyn \& Hoebel, 1941; Nader \& Todd, 1978).

This research has two theoretical focuses. First, following the central anthropological contention that property relations are to be understood as social relations and to be seen in terms of human society and culture (Firth, 1965; Gluckman, 1965; Hoebel, 1966; Malinowski, 1935), this paper explores how land property relations are not static, but shaped by complex cultural patterns and long-held traditions, as well as by the changing political economy. Second, drawing on theoretical developments in property studies since the 1980s that foreground issues of power (e.g., Appadurai, 1986; Coombe, 1998; Hann, 1998; Strathern, 1984, 1988; Verdery, 2003), the researcher views the formation of any type of property right as a fluid process within which social actors with different resources and capacities compete for control over various property elements such as rights, value, and meanings. Guided by these two theoretical focuses, this article examines how changed social and economic circumstances motivated individuals to redefine and defend their property rights, resulting in new norms and behavior patterns.

\section{Farmland as a Special Type of Family Property in China since the Early 1980s}

To understand how farmland is divided among rural families in China, we need to first understand what kind of property farmland constitutes in the specific social, political, and economic contexts of post-Mao China. Through a series of collectivization campaigns in the 1950s, the Chinese state abolished private land ownership and established collective land ownership. Village collectives have since become the formal owners of all farmland. For more than two decades, the majority of the rural populace was administratively bound to their collective units within the People's Commune System and was obligated to engage in collective labor. When the post-Mao reform began in the early 1980s, farmland was distributed to rural households through contracts. Rural families were freed from forced collective labor and reemerged as the primary production units (Chan, Madsen, \& Unger, 1992; Friedman, Pickowicz, \& Selden, 1991; Oi, 1989; Potter \& Potter, 1990; Ruf, 1998; Siu, 1989).

In Yuquan, as in many other rural areas in China, ordinary villagers and grass-roots leaders followed three principles to distribute land to individual households in 1982. Created to grapple with the issue of distributing farmland-the most crucial life resource, these principles reflect the prevailing attitude of the rural populace toward rights, equity, family, and community ( $\mathrm{Wu}$, 2016). The first principle is that membership in a village was needed to receive a share of land owned by the village. Every village had detailed rules on who could 
be defined as a native resident Egalitarianism among all eligible community members, regardless of gender and age, constituted the second principle guiding land allocation. The third principle indicates that the household was the land-receiving unit. Although land allocation was calculated in terms of individual entitlement, it was made to households. No individual family member's rights were specified on the land registry of a village or a land contract issued to a household. The main items listed were the name of the household head, the number of members in the household eligible for land allocation, and the amount and locations of land distributed to the household. In other words, individual land rights are abstract.

In Southwest China, rural households have kept the shares of land they originally received in the early 1980s, despite changes in family composition caused by birth, death, or marriage. This was because Southwest China is a mountainous region, where agricultural fields are different from each other in the amount of sunshine each receives, soil quality, distance from the residential area of the community, and so on. It thus became very difficult and complicated to reallocate the land to achieve an equal per capita landholding after the initial land allocation in the early $1980 \mathrm{~s}^{2}$ Within such a social and economic context, land has become a relatively stable, quasi-family property, which can be divided among and succeeded by family members when parents age or die, and when children grow up, marry, and set up their own households.

\section{The Cultural Norms of Property Division in Rural China}

In rural China, domestic property relations continue to be an arena where long-held norms regarding property rights between genders and generations reign. The government at all levels and the village administration generally refrain from intervening. As anthropologists and historians have long revealed, rural families in China go through a changing developmental process (Cohen, 1976; Ma, 1999). When children in a family reach the age of marriage, property division will become an inevitable and critical stage for family members. In a traditional family division, only males can inherit family property, and equality exists among the sons. Each son receives an equal share of family property, regardless of age, marital status, or residential arrangement, and each adult son is also responsible for supporting his parents in their later years.

Women, on the other hand, face different situations. They will not receive any family property when the family divides, but they are not obligate to provide

${ }^{2}$ The situation in the northern plains or the central part of China was very different. In these regions, land resources are scarce and population density especially is high, village communities reallocated farmland to households every few years according to the demographic changes in the households. The purpose of this frequent land reallocation was to maintain egalitarian per capita landholding within a community. In the new millennium, land redistribution declined sharply in the north and central regions, for two reasons: 1) the government policies that promoted the stability of rural land tenure relations for the purpose of encouraging large-scale farming and more efficient land use, and 2) rural-urban migration gradually reduced the population pressure on farmland in these regions (Kong \& Unger, 2013). As a result, the new millennium has witnessed relatively stable land tenure across China's vast countryside. 
old-age support to their parents either. In the early 1980s when farmland was initially distributed to rural households through contracts, all community members in a village, regardless of gender and age, had equal access to the collectively-owned land. In other words, women also received their shares of land, although, as indicated above, their shares were not specified in the family farmland contract. However, except in rare circumstances, age-old norms regarding family division and the post-marital residence often deprive women of the right to keep their shares of land after marriage or divorce. Women, as daughters or daughters-in-law, rely on family relationships to access land in a community. They have no sure means of independently holding their shares of land. For example, when a daughter marries, her share of land is often left for her parents or brothers, and she will leave her natal village to live in her husbands' community. In most rural areas in southwest China, the village of her husband will not provide her with any land; instead, she will work her husband's share of land. If this woman divorces her husband, it would be difficult for her to demand any major family property, such as land or houses. Most divorced women without children choose to live somewhere else, because her husband's community could be a hostile place to live. A divorced woman with children could choose to remain in her husband's village or move somewhere else. If a divorced woman decides to move to other places, her former husband's family usually wants the children to stay with their father, because these children are considered to be the members of the husband's lineage. A divorced woman with unmarried children may continue to live in the husbands' community, but any claim she makes for the family-contracted farmland can be questioned or even attacked by her former husband's family and community. The government and village administration tend to refrain from interfering with these traditional norms, despite the fact that the property law, inheritance law, and land laws all promote gender equality and individual rights (Sargeson, 2012; Sargeson \& Yu, 2010; Wu, 2016).

\section{A Rural Community Impacted by Urbanization and Migration}

Lotus Pond Village is located in the south of Yuquan County. Yuquan is a hinterland county in southwest China, with 11 townships. In general, the social and economic conditions of Yuquan in the first decade of the millennium resemble those of the vast economically less-developed regions of China. Located in the $\mathrm{H}$ Township of Yuquan, Lotus Pond is a social and economic center for nearby villages. It includes the township seat and a rural market that convenes on its main street every Sunday. In 2010, it had 327 households, a total of 1269 people. Before the new millennium, the overwhelming majority of villagers in Lotus Pond relied on farming for their basic livelihood. It had $1786 \mathrm{mu}$ of farmland, among which $259 \mathrm{mu}$ were rice paddy fields and $1527 \mathrm{mu}$ were dry land (One mu equals 0.165 acre, or 0.067 hectare).

Lotus Pond started to experience gradual urbanization in the late 1990s. Unlike other parts of China, especially the coastal region, where local industrial en- 
terprises were often the primary propeller of urbanization, urbanization in Lotus Pond was imposed by the government through various industrial and urban projects built on or near Lotus Pond's territories. To build industrial or commercial projects, the government expropriated farmland from Lotus Pond and nearby villages. Until 2010, following the government's land requisitions, close to one-third of the farmland in Lotus Pond was used to build a railroad, an inter-province highway, and a power plant. The life of local residents had been slowly changed as a result. First of all, agricultural incomes from the remaining farmland were not sufficient to support the villagers. One option to increase household incomes was to engage in various types of small business. More than a dozen of convenient stores and restaurants were opened to accommodate the needs of local residents and workers at the nearly power plant and the railway station. Local residents also ran small factories, garages, noodle processing shops, or family hotels. Another option for local residents to earn more money was to seek urban employment. Migration has been a significant feature of China's post-Mao reform, with large numbers of rural migrants moved to urban areas to seek jobs. While rural to urban migration became a constant social phenomenon in many parts of China in the mid-1980s, migration in Lotus Pond began quite slowly. Before the new millennium, only members from several households left the village and worked in the cities. Over the course of a decade, however, the number of migrant workers in Lotus Pond gradually increased. As of 2010, 174 of 327 households in Lotus Pond (53\%) had at least one household member working in the urban areas (for some households, the entire family moved to urban areas).

Gradual urbanization resulted in the increase of the value of rural land in China. Under the previous central planning economy in the Maoist era, land was considered to be neither a commodity nor an asset for producing economic wealth. In fact, China's land market was abolished in the late 1950s, and the Chinese Constitution banned all land transactions until 1988. All rural land was owned by village collectives and was prohibited to be bought or sold. In the post-Mao reform era, land became a commodity monopolized by the government. Through the operation of a land market it controls, the government requisitions land cheaply from farmers and then sells it to developers at a higher price. Within such a context, land changed from a non-commodity to a commodity that has different value to different social groups. The lion's share of the profits from land sales is obtained by the government and developers. Farmers received compensation after their land was requisitioned, but the compensation was unfair and didn't reflect the actual market value of the land ( $\mathrm{Wu}, 2016)$.

Although the amount of profit the government and developers could obtain from requisitioning and developing a $m u$ of farmland might not always be clear to villagers in Lotus Pond, they perceived the increasing value of their land at least through the gradually increasing compensation since the late 1990s. Between 1990 and 2010, a series of land requisitions took place in Lotus Pond. In 
1990 the township government decided to build a new paved road through the Lotus Pond to improve traffic conditions on the market day. Since the central government had no formal standard for compensation at that time, the township government simply took some farmland from local households without giving them any cash compensation. Village leaders used some extra land held by the village administration to compensate the families that had lost their land. In 1997, the second requisition took place because of the need to build a railroad passing through the south edge of Lotus Pond. At this time, the Land Management Law already stipulated how farmers should be compensated when their land was acquired. As a result, villagers in Lotus Pond were offered 3800 yuan per $m u$ of paddy and 3000 yuan for dry land. In 2002, more farmland in Lotus Pond was acquired to build an aluminium manufacturer. The compensation was 9200 yuan per mu of paddy field and 6500 yuan for dry land. In 2005 the local government decided to expropriate more farmland to build a new township center. The compensation for this fourth acquisition was 29,800 yuan per mu of paddy and 12,000 yuan for dry land. Five years later, the township center was expanded and nearby farmland owned by Lotus Pond was expropriated. Farmers whose land was expropriated were paid up to 74,000 yuan for a $m u$ of paddy and 60,000 yuan for a $m u$ of dry land. ${ }^{3}$ Again, the above compensations never reflected the market value of the land. Nevertheless, land did become property with potential cash value for villagers in Lotus Pond. For those villagers who lost their land in land requisitions, the compensation was crucial to their livelihood.

\section{Changing Perceptions, Emerging Norms}

Urbanization, the resultant increase of the value of rural land, and social mobility caused by rural-urban migration, constituted a changing social and economic context in which new perceptions and behavior regarding property rights emerged in Lotus Pond.

\subsection{The Contested Equality among Brothers and the Creation of New Norms}

What constitutes a fair property division-one based on traditional egalitarianism among sons or on labor investment or on fair access to economic resources? This question was at the heart of most land disputes between brothers who had left for urban employment for a long period of time and those who continued to live their native communities. Those brothers who remained in the village tended to have a stronger sense of entitlement to their family contracted farmland. New perceptions of fairness and rights could emerge, as illustrated by the case described below.

Zhao Lihong and Zhao Liling were two brothers. When land was distributed to households in the village in 1982, their father, a worker in a local factory, was

${ }^{3}$ One yuan equals approximately U.S. \$0.119 in 2005 and $\$ 0.161$ in 2010. 
not eligible for a share of village-owned land. The two brothers and their mother and sister received land as a household. The daughter of the Zhao family married and lived in another village. Her share of land remained in her natal family. In 1984 their father died. Zhao Lihong, the eldest son, took his father's place and became a worker. Their mother died soon after, without specifying how to divide the land between her two sons. After the death of the mother, the two brothers continued to live together and did not have a family division, because Zhao Liling was still a teenager. Two brothers maintained the land together, with Zhao Liling gradually taking on more responsibilities as he grew older. Zhao Lihong worked on farmland whenever he had time, since he was a factory worker.

After he got married in 1986, Zhao Lihong spent much less time farming. The land was mainly farmed by his wife and his younger brother. In the early 1990s, Zhao Liling got married and set up his own household. The land then became a divisive issue. In the view of the elder brother Zhao Lihong, the land should be divided equally between him and his younger brother, following the long-held custom. Zhao Liling, however, felt differently and thought he should take the major part of the land because, over the years, it was himself, not his elder brother, who bore the major responsibility for the farm work and paid agricultural taxes. He worked $1.2 \mathrm{mu}$ of land while his elder brother's wife worked only $0.4 \mathrm{mu}$. Also, as a factory worker, his elder brother already had a stable income source. It would only be fair that he, instead of his older brother, obtain more benefit from the family contracted farmland.

In 1999, the Chinese government renewed farmland contracts of rural households nationwide for another 30 years. In Yuquan County, the farmland originally distributed to a family in 1982 didn't change when farmland contracts were renewed. However, if a family divided their property, including land, among the sons, the village administration would issue each son a new land contract for the share of the land he received through the family division. Zhao Liling used this opportunity to outmaneuver his elder brother. He rushed to apply for a new land contract. Since the village administration knew he had been working on 1.2 $m u$ of their family-contracted farmland and paid the agricultural taxes, they issued him a new contract for the $1.2 \mathrm{mu}$ of land. For the village administration, they didn't care how a family divides its property, as long as the land was tilled and agricultural texts were paid. Zhao Lihong's wife was then given a new contract for the remaining $0.4 \mathrm{mu}$ of land.

Deeply upset by the fact that his younger brother took so much of the land, Zhao Lihong sought help from village cadres and the township legal assistance office. In 2001, after several rounds of mediation by the village administration and by the legal assistance office failed, Zhao Lihong simply planted seedlings in a $0.3 \mathrm{mu}$ rice paddy previously farmed by his younger brother and refused to allow his younger brother to use it. In 2004, Zhao Liling filed a law suit against his elder brother for violating his land-use rights. With the 1999 land contract in his hand, Zhao Liling easily won the case in the county court. Zhao Lihong was or- 
dered to return the $0.3 \mathrm{mu}$ rice paddy to his younger brother. Zhao Lihong then appealed to the prefecture court on the grounds that the family land should be divided equally among brothers, but his appeal was rejected, and the verdict of the county court was maintained. In this case, the judges at both the county court and prefecture court maintained that the new farmland contract-a formal legal document-was the basis for making their decision. The old custom emphasizing equality among brothers was not followed by the judges.

It is important to keep in mind that in most families, disputes didn't occur among brothers, who simply worked out new arrangements to handle family property division. Using the snowball method, the researcher interviewed 34 households in Lotus Pond who had family members working in urban areas in 2005. In total, the 34 households interviewed had 52 family members holding various kinds of urban jobs ( 31 men and 21 women). A stable urban job could be owing an urban business (e.g., a restaurant, hotel, barbershop, and convenience store), becoming a government employee, or becoming a college student with better employment prospects. Temporary urban jobs included construction workers, sales persons, babysitters, delivery persons, etc. Based on the interview data, the researcher found the following new patterns of property division:

First, among the 31 men who left their native community for urban jobs, those who had obtained stable employment opportunities were more likely to give up their shares of family property (family houses and land) and leave their shares to their parents or brothers (see Table 1). With stable urban jobs, these men often planned to live in cities permanently. The new perception of economic fairness greatly shaped the family division, as illustrated by the land division in the Zhang family. The Zhang family had 5 children, all of who were born after 1982 and therefore eligible for a share of farmland in the village. Among the five children, a daughter later went to professional schools and became an elementary school teacher in the township seat. One son became a county government employee. The daughter's share of land was kept by her parents. The son, who was eligible to keep his share of land according to the old custom, decided

Table 1. Choices for land disposition among males holding urban jobs in lotus pond.

\begin{tabular}{lcccc}
\hline & $\begin{array}{c}\text { Males intending to } \\
\text { keep their shares } \\
\text { of the farmland }\end{array}$ & $\begin{array}{c}\text { Males intending to leave } \\
\text { their shares of farmland } \\
\text { to parents or brothers }\end{array}$ & $\begin{array}{c}\text { Males who hadn't } \\
\text { made their } \\
\text { decisions yet }\end{array}$ & $\begin{array}{c}\text { Total } \\
\text { Number }\end{array}$ \\
\hline $\begin{array}{c}\text { With stable urban jobs } \\
\text { (including all ages) }\end{array}$ & 0 & 5 & 1 & 6 \\
$\begin{array}{c}\text { With temporary jobs } \\
\text { (age } 40 \text { or above) }\end{array}$ & 5 & 0 & 0 & 5 \\
$\begin{array}{c}\text { With temporary jobs } \\
\text { (age 30 - 40) }\end{array}$ & 8 & 1 & 0 & 9 \\
$\begin{array}{l}\text { With temporary jobs } \\
\text { (under 30 years old) }\end{array}$ & 2 & 8 & 1 & 11 \\
Total Number & 15 & 14 & 2 & 31 \\
\hline
\end{tabular}


to give his share of land to his youngest brother, who remained to be a farmer and lived with their parents. The youngest son was expected to take more responsibilities of taking care of the parents in their old age. Another form of a new arrangement could be that brothers with urban jobs left their shares of land to their rural brothers, who then were expected to provide their urban brothers with a symbolic amount of fresh produce every year. Whether each brother has a reliable income source, be it farmland or an urban job, became an important criterion for property division, including land.

Second, among rural males who held only temporary jobs in the cities, age was an important factor influencing their decision on domestic property division. As showed in Table 1, those who were over 40 years old tended to have the desire to keep their shares of land. While they might decide to let their parents or brothers living in the village farm their land temporarily, they often considered the land as a safety net and the last economic resource when they were too old to do physically demanding jobs in the cities. Among this group, the old norm of equal property division among brother was strongly held.

However, the younger generation (especially those under 30 ) showed much less desire to return to their native community in the future. For these young people, leaving for the cities were not solely motivated by the economic necessity of finding a way to make a living. Becoming wage earners and city-dwellers enabled them to extricate themselves from their current rural status and find opportunities for self-actualization. As a result, eight out of the 11 males under 30 years old planned to stay in the cities. Their shares of farmland, therefore, were maintained and kept by their parents or brothers.

To conclude, as increasing social mobility and economic opportunities caused more and more villagers to leave rural areas, the traditional equality principle guiding family property division among brothers may not be always easy to maintain. In most families with family members working in urban areas, new norms or new arrangements could emerge. For example, the family could pay more attention to whether each brother had an equal opportunity to a stable source of income, instead of focusing solely on dividing land equally among the brothers. This often resulted in an arrangement in which the brothers with urban jobs left their shares of land to their parents or brothers. Meanwhile, brothers living the village community would take more responsibility for taking care of their parents in old age. In other words, new perceptions of fairness emerged. It is also important to keep in mind that old norms didn't simply disappear or that new norms were easily accepted by all rural individuals. The specific life circumstances of each individual, such as age or job conditions, often decided what norms they would accept or create. Disputes and conflict could occur as a result, as illustrated by the case discussed above.

\subsection{The Emergence of Rights Consciousness among Women}

In addition to the changing norms guiding property division among brothers, 
the new social and economic environment also led to two other types of deviation from the traditional property division within a rural family. One is that parents' attitude toward their daughters were changing. Parents began to adopt a pragmatic attitude toward their old-age support and some even claimed that their shares of land would go to children who would dutifully support them in their older years, instead of simply being divided equally among the sons. Such a change could offer an opportunity for daughters, who traditionally cannot claim rights over family property when a family divided. Before the new millennium, there were three families in Lotus Pond who had uxorilocal marriage. ${ }^{4}$ In these families, parents left their shares of land to their daughters and sons-in-law. By 2010, however, in addition to the families with uxorilocal marriages, daughters in another three families-the Fu, Wang, and Liu Families-succeeded their parents' shares of land. Parents of the Fu family revealed that more convenient old age support was the leading factor for their decision on leaving their share of land to their daughter, due to family conflict (see the case discussed below). Parents of the Wang family decided to let their daughters have their land because of the need of the family business. The parents opened a small restaurant at the county seat and therefore didn't have time and energy to take care the land. With their only son working in a local coal mine, their daughter became the person who could take care the land. In the Liu family, the two sons worked as migrant workers in a coastal city and didn't plan to return to Lotus Pond. With health problems, the parents gave their land to their daughter, who built a successful pig farm on the land and also provided old-age support for her parents.

The other type of deviation from traditional property division was that daughters had started to demand their land rights. As rural women's property rights have been curtailed by the patrilocal post-marital residence and traditional family division norms, they face a disadvantaged position when trying to defend their land rights. It is unlikely for them to obtain support from traditional mechanisms (such as the mediation of kin or village leaders), an effective way for them to defend their rights therefore was to resort to formal legal channels. The following two cases can provide a window into women's new activism in defending their land rights.

The Fu Family case was a 6-year-long dispute between a woman and her brother over their parents' contracted farmland. The Fu family has two sons and two daughters. In 1982, the father, Fu Xiaosu, as the household head, received a total of six shares of farmland. In 1992, when the elder son, Fu Fawei got married, the family decided to divide its holdings. All property, including land, was divided into three equal shares. The father Fu Xiaosu and his wife got one share as their old-age-support land. Each of the two sons received a share. The two daughters received no property, although each was allocated a share of land in 1982.

After getting married, three of Fu Xiaosu's children remained in their natal village: the eldest son, Fu Fawei; the second son, Fu Faxiang; and the elder ${ }^{4}$ In rural China, if a family doesn't have a son, it could arrange an uxorilocal marriage for one daughter. In that case, the parents will live with the daughter and her marrying-in husband. 
daughter, Fu Weifen, whose husband was also from the same village. The younger daughter, Fu Cuifen, married into another village. To fulfill their responsibility as sons, Fu Xiaosu's two sons paid the agricultural taxes and other fees for their parents' share of land. ${ }^{5}$ They also assumed that their parents' land would be equally divided between them when their parents could no longer work the land. As time went by, however, the relationship between the father and his second son, Fu Faxiang, turned sour. In contrast, the father Fu Xiaosu and his wife remained close to their elder daughter, Fu Weifen, who lived in the same village and provided much help to her parents.

In 2000, Fu Xiaosu decided to give his share of land to the elder daughter $\mathrm{Fu}$ Weifen, who planned to use a quarter of the land to build a new house and the rest for farming. This arrangement was unusual because most parents wouldn't consider giving family property to daughters. While the elder son accepted this arrangement, the second son, Fu Faxiang, was upset. He believed that he was entitled to half of his father's land and viewed the fact that his sister took over all his father's land not only as a loss of property but also a serious insult because the decision showed that his father no long acknowledged him as a legitimate heir. Despite Fu Faxiang's disagreement, Fu Weigen began to build a new house. During construction, Fu Faxiang went to the site several times and tried to prevent the construction. By the time Fu Weifen's new house was finished, Fu Faxiang's simmering anger exploded-he smashed one of the new house's walls and plugged the recently dug well. He also dug up all the corn that was grow around the new house but not yet ready for harvest.

$\mathrm{Fu}$ Weifen demanded that her brother compensated her loss, and Fu Faxinag refused. Fu Weifen then asked the village administration for help. In 2002, after several rounds of mediation by the village leaders failed, Fu Weifen sued her brother in the county court for property damage and won the case. The court ordered Fu Faxiang to pay his sister 1500 yuan. However, the dispute was not resolved, because $\mathrm{Fu}$ Faxiang sued his sister for violating his land-use rights in 2003, because he had the renewed contract of his parents' share of land. Based on the fact he had paid the agricultural taxes of his parents' share of land for many years, Fu Faxiang requested a new land contract in 1999 when the government renewed all farmland contracts nationwide for another 30 years. The village administration issued the contract to Fu Faxing, because they didn't really care who was farming or using the land. From the perspective of the village leaders, how the land was divided among the Fu family was the Fu family's business. Facing such a thorny situation, the court considered the priority to be preventing conflict from escalating in the family. Both the court staff and village leaders then urged $\mathrm{Fu}$ Weifen to compromise and pay her brother some money. ${ }^{6}$ In the end, Fu Weifen agreed to pay 5000 yuan to her brother. The court agreed

\footnotetext{
${ }^{5}$ Agricultural taxes were eliminated in 2006 nationwide.

${ }^{6}$ To understand why the court handled the case this way, we need to explore many issues related to the operation of the legal system in China's rural areas, which are beyond the scope of this article. This article conveys only a brief summary of the case.
} 
to help her put the contract for the disputed land in her name.

In 2005, a dispute between brothers and their sister occurred in another family, the Li family, in Lotus Pond. In 1982, with 5 family members-the parents, two sons, and one daughter, the Lis received a total of five shares of farmland. When the children grew up and were married, the farmland distributed to the family was divided into three equal shares among the households of the two sons and the parents. Again, the daughter, who married and lived in another village, didn't get any property. As in the Fu family described above, no disputes occurred during this initial family division. Later the parents turned their share of land, which was a piece of sloping field, into a pear orchard. The two sons and the daughter all helped to develop and maintain the orchard.

When the new township center was expanded in 2005, the pear orchard was acquired by the local government. The parents received substantially more compensation than farmers with regular agricultural plots, because, according to the compensation policy, each fruit tree in the orchard received additional compensation. The parents then decided to divide the compensation into three shares among the two sons and themselves. However, the daughter also wished to share the land requisition compensation, based on the fact that she not only received a share of land in 1982, but also contributed to the maintenance of the orchard. She first tried to persuade her parents to let her share part of the compensation. But her parents and two brothers were not willing to do so, resulting in a prolonged family dispute. The village administration supported the parents' decision for the reason that the daughter was no longer a member of Lotus Pond, but a member of her husband's village; therefore, she was not eligible to receive the benefits brought about by the land belonging to Lotus Pond. Seeing that she would not receive support from the village administration, the daughter decided to go to the county court to settle the issue. At the court, the daughter proved that she received a share of farmland in 1982. However, the current farmland contract that was renewed in 1999 was in the hands of the parents. Based on the current contracts, the judge determined that the daughter didn't have the right to share the compensation for land requisition.

In the same year when the township center was expanded, similar disagreements occurred in several other families when daughters who married and lived in other villages came back to their natal families to demand their shares of compensations. But none of these women resorted to legal channels to solve the issue, and none of them were successful in obtaining the compensations.

To sum up, in Lotus Pond, the overwhelming majority of women continued to follow the traditional norms regarding the property rights between different genders. However, social mobility and economic opportunities had caused at least some families to be flexible and pragmatic in arranging its domestic property divisions. Parents might not always choose sons as the successors of their property, leaving some opportunities for daughters. Moreover, as the value of rural land increased with urbanization, a few women started to demand their 
land rights. Such new behavior shed light on the emergence of rights consciousness among women, especially given that some of them chose to use formal legal channels to defend their rights and interests.

\section{Conclusion}

In China's rural communities, domestic property relations have been an arena where long-held norms regarding rights and responsibilities between genders and generations reign. The government at all levels tends to refrain from intervening. Due to the influence of these norms, the household, instead of the individual, has long been a property holding unit. When a family divides, property, including land, is divided equally only among sons; daughters are excluded from succeeding/inheriting family property. However, these cultural norms are subject to change in the changing political economy of contemporary China. This article uses the division of the family contracted farmland as an entry point to explore how long-held customs had begun to be contested and negotiated among rural individuals when the broader social and economic contexts changed as a result of China's post-Mao economic reform.

Land constitutes a special type of property in China. The collectivization program initiated by the Chinese socialist state in the 1950s abolished private land ownership and made village collectives the formal owners of rural land. Moreover, rural land was prohibited to be bought or sold. When the post-Mao economic reform began in the 1980s, the collectively-owned farmland was distributed to rural households, who reemerged as the primary unit of agricultural production instead of being obligated to participate in collective labor. As rural families hold long-term farmland contracts, farmland became a special type of property that can be divided and succeeded among family members when parents age or die, and when children grow up and marry. Moreover, as a land market monopolized by the government was created in the post-Mao era, land also became a commodity that can bring different value to different social actors.

Situated in Lotus Pond, a village community in Southwest China, this research explores how the changing social and economic contexts in the first decade of the new millennium made the definition of rights over farmland a fluid process during which social actors with different resources competed for the control over various property elements such as rights, value, and meanings. Located in a hinterland county in China's less-developed regions, Lotus Pond experienced two social changes at the beginning of the new millennium. The first one is the urbanization process, as its farmland was acquired by the government for industrial and commercial projects. Unlike the situation in the Maoist era when farmland was treated as a collective asset that could only be used for agricultural purposes and was prohibited to be sold or bought, urbanization turned rural land from a previous non-commodity to a special commodity. For villagers in Lotus Pond, farmland means a basic means of making a living in everyday life. When their land was requisitioned by the government for industrial or commer- 
cial projects, the compensation became a financial source crucial to villagers' life after the requisition. Although the value of rural land varies greatly among social actors, the rapid increase of the value of rural land had been perceived by local residents. The second change that Lotus Pond started to experience is rural-urban migration. More and more villagers sought economic opportunities in the cities, and farming was no longer the only primary source of income. Until 2010, half of the households in Lotus Pond had at least one family member working in urban areas. Their jobs varied: some obtained stable urban jobs and planned to live in the cities permanently, while others had temporary jobs and intended to return to their natal community once making a living in the cities became infeasible.

As urbanization and social mobility started to impact the social and economic fabric of Lotus Pond, local residents' perceptions and behavior regarding property rights also started to change. Land meant different things to family members with different life circumstances. Within this changed context, it may not always be easy to uphold the traditional norm of dividing family property equally among sons or the norm of prohibiting daughters from succeeding family property. Although old norms continue to prevail, new arrangements of family property division and new perceptions of fairness emerged. Conflicts and disputes also broke out.

For males with temporary and unstable urban jobs, they tended to have the desire to keep their shares of land in case they could no longer make a living in the cities. In other words, the traditional norm of equality among sons still held. However, when some males had stable urban jobs, what could constitute a fair family division was subject to redefinition. That every brother should have a stable income source began to be accepted as a new norm, which often made brothers with stable urban jobs less eligible for an equal share of the family contracted farmland in the eyes of their rural brothers. Being practical was another issue affecting property division among brothers. For those with stable urban jobs, maintaining their shares of farmland was not considered as practical or desirable. They often chose to leave their land to their brothers or parents who continued to live in the village. Taking care of parents in their old age usually became the responsibilities of their rural brothers. Age is also another factor shaping people's choice over property division. Becoming wage earners in the cities became a life aspiration for many males under 30 years old, who had less desire to keep their shares of farmland.

The absence of sons in the rural families caused by social mobility could be a reason for changing parent attitudes. Parents could become more pragmatic when planning their old-age support and might not always pass their property/land to the sons. The non-traditional arraignments made it possible for some women to inherit/succeed family property. Moreover, as women perceived the increasing value of rural land, they might not passively obey the traditional norms of prohibiting women from inheriting/succeeding property. A few of 
them in Lotus Pond started to demand their land rights. Rural women's property rights have been curtailed by the patrilocal post-marital residence and traditional family division norms. Such a disadvantaged position often caused them to use law to defend themselves, instead of relying on the support of their families or community. In the case of the Fu family, the sister was not hesitant to sue her brother when he damaged her property. In the Li family case, the daughter went to court to demand an equal share of the compensation for the acquired orchard. To a certain extent, the law offers women a new opportunity to defend themselves, when their social resources are limited by traditions and customs.

As the first part of a larger project on the changing property rights of rural individuals, this article focuses on the new perceptions and behavior that emerged in Lotus Pond in the first decade of the new millennium. Data from this period is important, because it serves as a basis for studying perceptions and behavior patterns in the second decade of the new millennium. Lotus Pond experienced even more profound changes after 2010. As of 2018, close to half of its farmland was turned into commercial and industrial projects. Up to $68 \%$ of the households in Lotus Pond had at least one family member working in urban areas. Such changes were compounded by the fact that uniform certificates for rural land-use rights were issued to rural households across the country between 2012-2017. Most rural households receiving their original farmland contracts in the early 1980s needed to readjust the members listed on the new land certificates, due to demographic changes caused by death, birth, marriage, family division, or social mobility over the past 30 years. Who may be listed on the new land certificates became another issue that can yield information on the changed perceptions and behavior of individuals regarding property rights. To understand how profoundly changing social and economic environment could generate even more significantly changed perceptions and behavior, it is important to assess the situation in the earlier stage, which is the purpose of this article.

\section{Acknowledgements}

Major funding for the fieldwork on which this research was based was provided by the Law and Social Science Program of the National Science Foundation and the Wenner-Gren Foundation for the Anthropological Research.

\section{Conflicts of Interest}

The author declares no conflicts of interest regarding the publication of this paper.

\section{References}

Appadurai, A. (1986). Introduction: Commodities and the Politics of Value. In A. Appadurai (Ed.), The Social Life of Things (pp. 3-63). New York: Cambridge University Press. https://doi.org/10.1017/CBO9780511819582.003

Chan, A., Madsen, R., \& Unger, J. (1992). Chen Village Under Mao and Deng. Berkeley, 
CA: Univeristy of California Press.

Cohen, M. L. (1976). House United, House Divided: The Chinese Family in Taiwan. New York: Columbia Univeristy Press.

Coombe, R. (1998). The Culutral Life of Intellectual Propoerties. Durham, NC: Duke University Press. https://doi.org/10.1215/9780822382492

Firth, R. (1965). Primitive Polynesian Economy. London: Routledge \& Kegan Paul.

Friedman, E., Pickowicz, P., \& Selden, M. (1991). Chinese Village, Socialist State. New Haven, CT: Yale Univeristy Press.

Gluckman, M. (1965). The Ideas in Barotse Jurisprudence. New Haven, CT: Yale University Press.

Hann, C. M. (1998). Property Relations. Renewing the Anthropological Tradition. Cambridge: Cambridge University Press.

Hoebel, E. A. (1966). Anthropology: The Study of Man. New York: McGraw-Hill.

Kung, S., \& Unger, J. (2013). Egalitarian Redistribution of Agricultural Land in China through Community Consensus: Findings from Two Surveys. The China Journal, 69, $1-19$.

Llewellyn, K. N., \& Hoebel, E. (1941). The Cheyenne Way: Conflict and Case Law in Primitive Jurisprudence. Norman: University of Okloahoma Press.

Ma, G. (1999). The Family and the Social Structure of China. Beijing: Wenwu Chubanshe.

Malinowski, B. (1935). Coral Gardens and Their Magic. London: Allen and Unwin.

Nader, L., \& Todd, H. F. (1978). The Disputing Process: Law in Then Societies. New York: Columbia Univeristy Press. https://doi.org/10.7312/nade93322

Oi, J. C. (1989). State and Peasant in Contempoary China. Berkeley, CA: University of California Press.

Potter, J. M., \& Potter, S. (1990). China's Peasants. An Anthropology of Revolution. Cambridge, CA: Stanford Univeristy Press. https://doi.org/10.1017/CBO9780511607783

Ruf, G. (1998). Cadres and Kin: Making a Socialist Village in West China, 1921-1991. Stanford, CA: Stanford Univresity Press.

Sargeson, S. (2012). Villains, Victims, and Aspiring Proprietors: Framing "Land-Losing Villagers" in China's Strategies of Accumulation. Journal of Contemporary China, 21, 757-777. https://doi.org/10.1080/10670564.2012.684962

Sargeson, S., \& Song, Y. (2010). Land Expropriationn and the Gender Politics of Citizenship in the Urban Frontier. The China Journal, 66, 19-45.

https://doi.org/10.1086/tcj.64.20749245

Siu, H. (1989). Agents and Victims in South China: Accomplices in Rural Revolution. New Haven, CT: Yale University Press. https://doi.org/10.2307/j.ctt2250x73

Strathern, M. (1984). Subject or Object: Women and the Circulation of Valuables in Highlands New Guinea. In R. Hirschon (Ed.), Women and Propert, Women as Property (pp. 158-175). London: Croom Helm.

Strathern, M. (1988). Then Gender of the Gift. Problems with Women and Problems with Society in Melanesia. Berkeley, CA: University of California Press. https://doi.org/10.1525/california/9780520064232.001.0001

Verdery, K. (2003). The Vanishing Hectare: Property and Value in Postsocialist Transylvania. Ithaca, NY: Cornell University Press. 
Wu, Y. (2016). Negotiating Rural Land Ownership in Southwest China: State, Village, Family. Honolulu, HI: University of Hawai'i Press.

https://doi.org/10.21313/hawaii/9780824846770.001.0001 